Соња Ивановић

Библиотека Матице српске, Нови Сад

sivanovic@bms.ns.ac.rs

Милица Мирчић

Библиотека, Медицински факултет

Универзитета у Новом Саду

milica.mircic@mf.uns.ac.rs
Стручни рад

UDK 027.1 Берић Б. 61:929 Берић Б.

027.54(497.113)

https://doi.org/10.18485/

bibliotekar.2018.60.1.5

\title{
ПОКЛОН БИБЛИОТЕКА АКАДЕМИКА БЕРИСЛАВА М. БЕРИЋА
}

Сажетак: У раду су представљени биографија и стручна библиотека из области медицине и акушерства Берислава М. Берића која је примљена као поклон у Библиотеку Матице српске 2006. године. Берислав М. Берић био је угледни новосадски лекар-специјалиста гинекологије и акушерства и универзитетски професор, аутор неколико уџбеника и монографија објављених на територији бивше Југославије. Бавио се питањем здравствене заштите жене, хумане репродукције и планирања породице а на ову тему је објавио и бројне научне радове. Поклон библиотека проф. Берића садржи велики број страних издања која ову колекцију чине изузетно вредном, јер неретко је реч о јединим примерцима ових публикација код нас. Она такође указују и на професионална интересовања власника збирке. Превасходно је реч о стручним публикацијама попут уџбеника, практикума, медицинских лексикона и речника, као и зборника, саопштења и резимеа са стручних скупова одржаних у земљи и иностранству.

Кључне речи: Берислав М. Берић, личне библиотеке, библиотеке целине, Библиотека Матице српске, историја медицине. 
Библиотека Матице српске посебну пажњу посвећује легатима и личним библиотекама, тј. библиотекама целинама ${ }^{1}$ које имају изузетан културно-историјски значај и које сачињавају важан део фонда ове установе. У њој се чува око четрдесет личних библиотека истакнутих личности, а међу њима је своје место нашла и библиотека академика Берислава М. Берића, угледног лекара-специјалисте гинекологије и акушерства и универзитетског професора. ${ }^{2}$

Берислав М. Берић рођен је 11. 11. 1927. у Београду, у угледној грађанској породици. Његов отац, Миленко Б. Берић, такође је био лекар гинеколог-акушер, а мајка Олга Берић, рођена Пушић, студирала је на Музичкој академији у Бечу и течно је говорила неколико страних језика. ${ }^{3}$

Берић је одрастао у Београду, где је завршио основну, а као питомац Дома и гимназије краља Александра I започео је и средњу школу. Други светски рат прекинуо је његово школовање, због чега је матурирао тек после демобилизације из НОБЈ 1946. у Новом Саду. Студије медицине уписао је у Загребу, али их наставља у Београду, где је и дипломирао 1952. Веома брзо је започео специјализацију из гинекологије и акушерства у Скопљу и Битољу, да би завршни део специјалистичког стажа и специјалистички испит положио са одличним успехом 1956. на Гинеколошко-акушерској клиници Медицинског факултета у Београду. Своје даље усавршавање наставља у болници у Лозани, а потом на клиникама у Женеви, Хајделбергу, Хамбургу, Килу, Штокхолму и Бону. Године 1960. докторирао је на Медицинском факултету у Београду са тезом: „Хистотопохемијска испитивања полисахарида и нуклеинских киселина епителијалних тумора оваријума

1 „Библиотеке целине могу ући у фонд било које јавне библиотеке (или неке друге институције, архива или музеја) откупом, поклоном или тестаментарним завештањем законитог власника неке такве збирке. Само оне библиотеке целине које су тестаментом предате некој јавној библиотеци или било којој другој институцији, а које иначе не би имале право на ово наслеђе, називају се легатима, а страна која их уступа је легатор." (Светлана Мирчов, „Библиотеке целине и библиотеке легати”, Гласник НБС, 2004, бр. 1, стр. 11.)

2 О личним библиотекама у БМС видети у: Радивој Додеровић, „Библиотеке целине и легати у Библиотеци Матице српске”, у [Легати и библиотеке целине] : Библионет 2016, уредници Татјана Брзуловић Станисављевић, Мирко Демић (Београд: Заједница матичних библиотека Србије; Крагујевац: Народна библиотека „Вук Караџић”, 2016), 120-164.

3 Душан Попов, ур., Енциклопедија Новог Сада. Св. 3, Баб-Боа (Нови Сад: Новосадски клуб: Добра Вест, 1995), 219-220. 
са обзиром на питање њихове номенклатуре, класификације, хистогенезе и терапије”.

Берић је веома рано започео каријеру наставника и предавача. У периоду од 1958. до 1960. предавао је на Медицинском факултету у Сарајеву, где је стекао звање доцента. Након тога, као стипендиста Хумболтове фондације, усавршава се на Гинеколошкој клиници Медицинског факултета у Килу (1960/61) где је изабран за првог наставника за предмет Акушерство

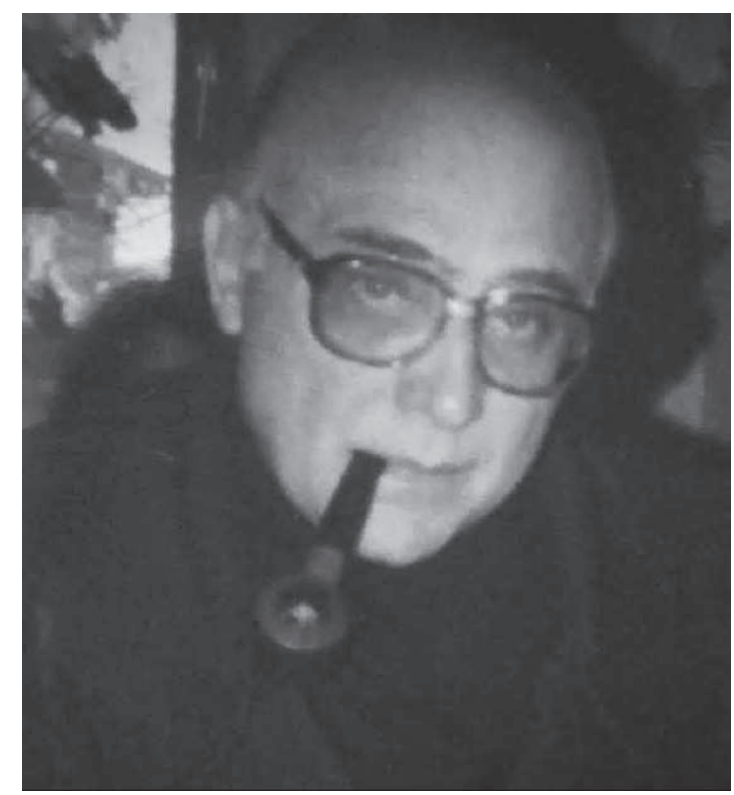

Академик Берислав М. Берић

и гинекологија. Године 1961. почиње да ради на Медицинском факултету у Новом Саду. За ванредног професора изабран је 1967, а за редовног 1972. У периоду од 1968. до 1974. обављао је функцију шефа Катедре и био је управник Клинике за гинекологију и акушерство у Новом Саду. Средином седамдесетих година прошлог века одлази у Канаду где је радио као професор и директор Клинике за гинекологију и акушерство Универзитета у Шербруку (1974/75), а потом у Француску где је предавао Увод у хуману репродукцију на École Nationale de la Santé de la République de France у Рену (1975/77). Године 1975. изабран је за начелника Завода за хуману репродукцију на Клиници за гинекологију и акушерство у Новом Саду на којој је радио све до пензионисања 1993. 
Овај изузетан педагог такође је аутор и један од уредника бројних универзитетских уџбеника објављених на територији бивше Југославије (32 уџбеника и монографије). У сарадњи са Д. Т. Поповићем, М. Стевановим, Б. Петрићем и Б. Капамаџијом у наставни програм увео је поглавље које се бавило форензичком гинекологијом и перинатологијом. Бавио се питањем здравствене заштите жене, хумане репродукције и планирања породице. Објавио је бројне научне радове на ту тему, али и на стотине чланака у дневним листовима и часописима намењених широј популацији.

Током свог научноистраживачког рада који је трајао преко 40 година, Б. Берић је објавио велики број публикација. Реч је пре свега о монографијама и универзитетским уџбеницима (24 код нас и 7 у иностранству), научним и стручним радовима (483 рада) и здравственоваспитним чланцима у часописима (110 чланака, 12 агитки). Такође је снимио и један научни филм. Библиографију радова Б. Берића објавила је ВАНУ 1992. у Новом Саду. Због изузетно богатог и разноврсног опуса тешко је направити праву систематизацију дела овог академика. У Билитену Меgицинскоі факулйей (бр. 74 из 1972) наведено је више области којима се Б. Берић бавио у свом научноистраживачком раду:

- іинеколошка ендокринолоіија (преко 50 радова),

- колйоскойија и ичинеколошка онколоіија (15 радова и први уџбеник Клиничка колйоскойија објављен код нас 1977, написао заједно са Д. Поповићем),

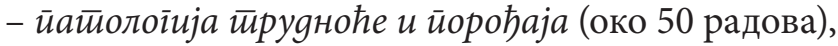

- ирроблеми инфанйилне и јувенилне іинеколоїије (око 35 радова),

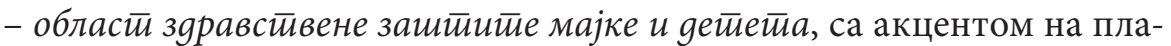
нирању породице, регулације фертилитета и хумане репродукције. У овој области изнео је своју тезу о четири фазе развоја и транзиције феномена планирања породице у ширим друштвеним и географским размерама (желећи да искажу признање за рад на овом плану, Извршно веће Војводине, Универзитет у Новом Саду и Матица српска дали су Међународном симпозијуму о одрживом регионалном демографском развоју назив „Академик Берислав Бета Берић”),

- форензичка іинеколоїија и йородилстивво (у овој области сарађивао је са судским медицинарима, психијатрима, правницима, педијатрима, генетичарима и др.)

4 Билтен Медицинског факултета у Новом Саду бр. 74 (1972): 11-34. 
- истиорија меgицине (формирао је мултидисциплинарни Научни одбор за проучавање Историје медицине на тлу данашње Војводине који су сачињавали Матица српска, Српска академија наука и уметности - Огранак у Новом Саду и Универзитет у Новом Саду. На Берићеву иницијативу Матица српска покренула је посебну едицију на ту тему),

- универзитеитска настиява из областии іинеколоїие и акушерстива (као ментор докторских дисертација и магистарских радова допринео је научном унапређивању кадрова; организовао је научне скупове и био је члан редакционих одбора симпозијума).

Требало би истаћи и Берићев допринос развоју институција у којима је радио или којима је руководио. Био је стални стручни сарадник Матице српске и секретар Одељења за природне науке. У периоду од 1988. до 1992. био је генерални секретар ВАНУ, а од 1992. постаје и редовни члан САНУ. О његовом статусу на међународној научној сцени најбоље говоре његова бројна чланства и функције у међународним научним удружењима и организацијама. Поред тога што је био генерални секретар Интернационалне федерације за инфантилну и јувенилну гинекологију (FIGIJ) и консултант Светске здравствене организације за планирање породице и заштиту мајке и детета са мисијама у Египту, Алжиру, Ираку, Либану, Кипру и Финској, треба истаћи и његово чланство у Интернационалној академији за цитологију у Њујорку, као и место председника Стручног савеза Интернационалног центра за истраживање побачаја. Био је члан и Интернационалне академије за репродуктивну медицину у Рио де Жанеиру, као и бројних других светских друштава и научних савета. Добитник је великог броја признања (медаља, плакета, повеља, захвалница, диплома итд.). О његовом животу и раду писано је у домаћим и страним енциклопедијама. Једна улица у Новом Саду носи његово име. ${ }^{5}$

Библиотека академика Берића примљена је у Библиотеку Матице српске почетком 2006. године, као поклон његове супруге проф. др Весне Берић и кћерке Андријане Берић. Да се ова богата стручна библиотека из области гинекологије, акушерства, хумане репродукције, планирања породице, гинеколошке онкологије и историје медицине нађе у фонду библиотеке била је свакако и жеља покојног академика Берића. Уговор са

5 Драгиша Т. Поповић, „Берислав М. Берић (1927-1994)”, у Живот и дело српских научника, уредник Владан Д. Ђорђевић. (Београд: САНУ, 2014), 393-446. 
поклонодавцима потписао је управник Библиотеке Матице српске Миро Вуксановић 28. децембра 2005. године 6 . Најважније ставке тог уговора су: поклон библиотека од око 1.000 књига биће стручно обрађена и добиће своју сигнатуру „Берић”, користиће се само у просторијама Библиотеке, а услуге коришћења биће бесплатне. Уговором је прецизирано да ће се библиотека звати „Поклон библиотека академика Берислава М. Берића”.

Библиотека је након стручне обраде и сигнирања смештена у посебан део магацинског простора Библиотеке Матице српске. У електронској бази библиотеке обрађено је укупно 919 публикација са сигнатуром „Берић”. Као и у већини личних библиотека, основу чине монографске публикације. У Берићевој библиотеци има их укупно 888. Кад је реч о серијским публикацијама, унет је 31 наслов периодике. Осим на српском и хрватском језику (283), библиотека садржи и публикације на страним језицима. Најзаступљније су оне на немачком (287), потом на енглеском (183), француском (109), мађарском (5) и многим другим језицима (македонском, румунском, италијанском, грчком, бугарском, данском). Овако велики број страних издања ову колекцију чини изузетно вредном јер неретко је реч о јединим примерцима ових публикација код нас. Она такође указују и на професионална интересовања власника збирке. Превасходно је реч о стручним публикацијама попут уџбеника, практикума, медицинских лексикона и речника, као и зборника, саопштења и резимеа са стручних скупова одржаних у земљи и иностранству.

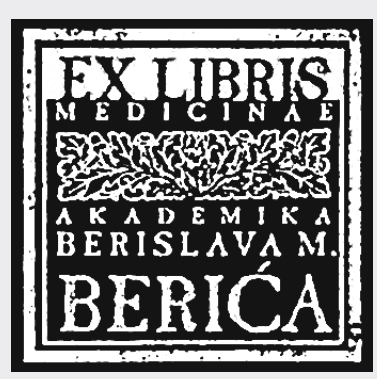

Веома често примерци публикација које су биле у личном власништву неког истакнутог појединца носе лични печат свог власника у виду потписа, посвете или екслибриса који је власник сам израдио за своју

6 Архива Библиотеке Матице српске: бр. 0301-2088. 
библиотеку. На већини публикација у овој збирци налази се екслибрис академика Берића. На некима од њих утиснута су два екслибриса - један на коме пише „Ex libris akademika Berislava M. Berića” и други на коме стоји „Ex libris medicinae akademika Berislava M. Berića”.

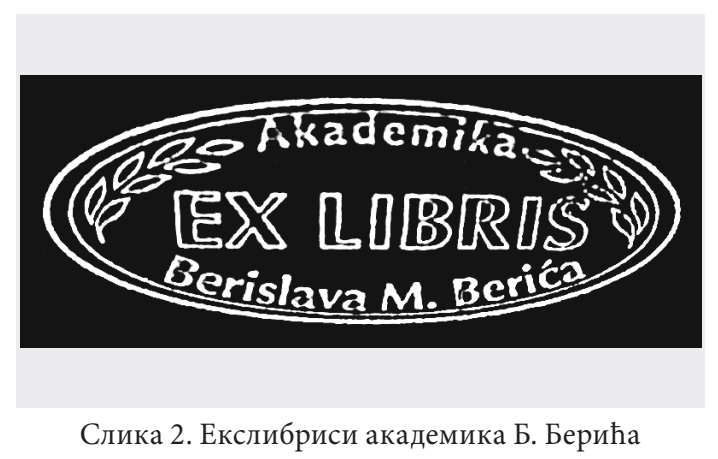

Кад је реч о посветама, њих у овој збирци нема много. Издваја се свакако посвета Асима Курјака, чувеног лекара гинеколога и стручњака у области ултразвучне дијагностике и неколико посвета страних аутора (X. Л. Котмајер (H. L. Kottmeier), Г. Гретсас (G. Greatsas), Лари Раурамо (Lauri Rauramo) и др.)

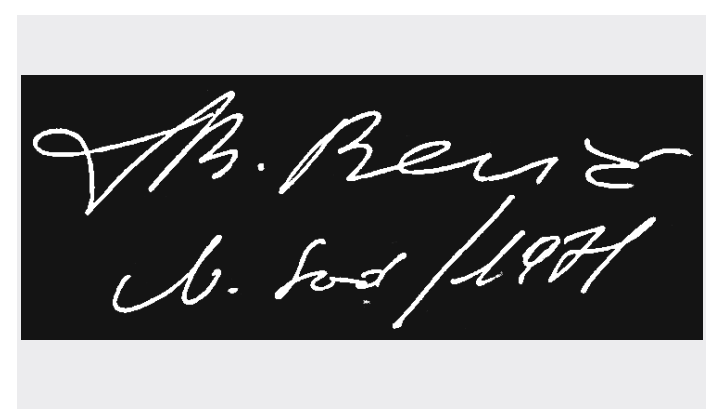

Слика 3. Потпис академика Б. Берића

Књига коју у оквиру библиотеке академика Берића вреди посебно споменути носи назив Основи науке о йорођајима и може се сматрати првим уџбеником акушерства код нас. Написао ју је и објавио 1925. др Миладин Свињарев Величковић, шеф Гинеколошког одељења Државне болнице у Новом Саду. У предговору ове књиге аутор истиче да је студентима и лекарима на специјалистичким студијама неопходна стручна литература 
на матерњем језику, те је тако изразио жељу да им пренесе део свог богатог знања из области гинекологије и акушерства. Уџбеник посвећује „Племенитој сени велике српске добротворке баронице Еуфемије Јовић, рођ). Јанковић”, захвалан на стипендији за студије медицине у Будимпешти.

На 502 стране уџбеника др Миладин Свињарев Величковић пише о акушерству и основама неонатологије. Осим предговора и дела о историји породиљства, књига је подељена на пет делова. Први део посвећен је ембриологији плода и анатомији женске карлице. Други део описује трудноћу, њен нормалан ток све до порођаја, али се осврће и на неке од честих неправилности и компликација. Трећи део говори о патологији трудноће, укључујући илустрације и описе техника неких интервенција и хируршких операција. У четвртом делу је описан патолошки порођај са посебним освртом на проблеме сепсе и на друге инфекције након порођаја. Пети део уџбеника посвећен је новорођенчету, а написао га је Ђура Јовановић, специјалиста за дечије болести. У књизи се налази 220 слика. Цртеже су радили Ј. Гризингер и Ф. Фишер из Новог Сада. Оригинални снимци добијени су од угледних колега са бечких института, а једним делом су припадали и самом аутору.

Следећа занимљива књига у оквиру ове библиотеке је Die Abtreibung, што у преводу са немачког значи абортус, а издваја се због веома квалитетних илустрација које се у њој налазе. Ова медицинско-социолошка студија, објављена 1927, била је намењена докторима, правницима и социолозима, имајући у виду да је абортус у то време практикован не само као једна од контрацептивних опција, него и као основна метода планирања породице која се није увек успешно окончавала. Аутор Вилхелм Липман (Wilhelm Lippman) био је управник немачког Института за здравље жена и он је на 24 странице описао ужасне, негативне последице илегалног абортуса. Илустрације које је радила Мари Симонс Вендланд (Mary Simons Wendland) представљају 24 графике у боји и оне су уметнички и поучан приказ нежељених трудноћа, контрацепције, абортуса и стерилизације.

Колпоскопија је била једна од специјалности проф. Берића. Он је аутор првог уџбеника о колпоскопији у Југославији. У његовом легату налази се мноштво наслова посвећених овој теми, али свакако треба истаћи оне на којима је име немачког гинеколога Ханса Хинселмана (Hans Hinselmann), зачетника ове методе. Реч је пре свега о два зборника на немачком језику из 1966. и 1969. чији је био уредник (Kolposkopische und Zytologische Studien in zwangloser Folge: Fortsetzung der kolposkopischen Studien von H. C. Hinselmann) и о једној публикацији на француском језику (Introduction à la Colposcopie) из 1938. чији је аутор. Иако је колпоскопија била прва научна метода за рано 
откривање рака грлића материце којој се и данас милиони жена свакодневно подвргавају, Хинселману се оспоравају почасти јер је део експеримената под његовим надзором спровођен на жртвама холокауста у Аушвицу.

Вредан помена је свакако и први број часописа Proceedings of the Royal Society of Medicine из 1908, који је под тим називом постојао све до 1977. Претходио му је часопис под називом Medico-Chirurgical Transactions из 1809. године, а наследио га је Journal of the Royal Society of Medicine који излази од 1978. све до данас, што говори о томе да овај часопис постоји више од двеста година и да је редак показатељ историје и еволуције медицинске професије. Према данашњим мерилима овај часопис се сматра врхунским научним часописом са релевантним бројем цитираних радова. У оквиру редакције овог часописа постојало је укупно 13 секција. Познати почасни чланови редакције били су Чарлс Дарвин (Charles Darwin), Луј Пастер (Louis Pasteur), Едвард Џенер (Edward Jenner), Сигмунд Фројд (Sigmund Freud) и др.

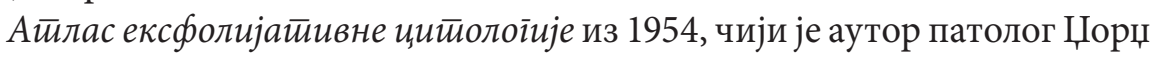
Папаниколау (Georgios Papanikolaou), јединствен је у дијагностичкој цитологији. У њему се налазе изврсне илустрације, теоријски и нешто краћи практични текстови. Илустрације у боји приказују корелацију између хистопатолошких и цитолошких налаза нормалних и малигних ћелија. Има их укупно 36 (24 цртежа и 12 фотомикрографија). Ћелијске мембране, једра и друге ћелијске структуре су невероватно прецизно и јасно приказане, потврђујући велику важност ексфолијативне цитологије као нове дијагностичке гране у патологији. Овај атлас се не бави само питањима женских гениталних малигних обољења, већ и патологијом урогениталног система мушкараца, затим респираторним и гастроинтестиналним системом и изливима у грудну и абдоминалну шупљину, као и патологијом дојке. Папа тест, који је данас рутинска дијагностичка метода за рано откривање рака грлића материце, носи име по овом аутору. Корице су у форми регистратора, а странице повезане металним механизмом са прстеновима који омогућавају додавање листова. Према ауторовој жељи, идеја је да свако може да ажурира свој атлас најновијим сазнањима из ове области, чинећи га увек савременим и корисним.

Библиотека Б. Берића није у потпуности заокружена свим предвиђеним материјалом. Реч је о библиотеци у настајању којој би у наредном периоду требало придодати још око педесет наслова. Када то буде учиње- 
но, ова изузетно вредна збирка биће целовита и као таква служиће свим заинтересованим корисницима и истраживачима на пољу медицине, гинекологије и акушерства.

\section{Литература:}

1. Doderović, Radivoj. „Biblioteke celine i legati u Biblioteci Matice srpske”. U [Legati i biblioteke celine]: Biblionet 2016, urednici Tatjana Brzulović Stanisavljević, Mirko Demić, 120-164. Beograd: Zajednica matičnih biblioteka Srbije; Kragujevac: Narodna biblioteka „Vuk Karadžić”, 2016. (na ćirilici)

2. Matović, Marijana. „Legati (biblioteke celine) i lične biblioteke u Čačku: srpsko zadužbinarsko nasleđe". U Zbornik radova Narodnog muzeja, urednik Delfina Rajić, 275-332. Čačak: Narodni muzej, 2005. (na ćirilici)

3. Mirčov, Svetlana. „Biblioteke celine i biblioteke legati”. Glasnik Narodne biblioteke Srbije br. 1 (2004): 11-16. (na ćirilici)

4. Popov, Dušan, ur. Enciklopedija Novog Sada. Sv. 3, Bab-Boa. Novi Sad: Novosadski klub: Dobra Vest, 1995. (na ćirilici)

5. Popović, Dragiša T. „Berislav M. Berić (1927-1994)”. U Život i delo srpskih naučnika, urednik Vladan D. Đorđević. Beograd: SANU, 2014. (na ćirilici)

6. Prelić, Velibor. „Legati i biblioteke celine u Narodnoj Biblioteci Srbije”. Glasnik Narodne biblioteke Srbije, (2012/2013): 157-164. (na ćirilici) 
Sonja Ivanović

Matica Srpska Library, Novi Sad

sivanovic@bms.ns.ac.rs

Milica Mirčić

Faculty of Medicine, University of Novi Sad

milica.mircic@mf.uns.ac.rs

\title{
DONATED COLLECTION OF ACADEMICIAN BERISLAV M. BERIĆ
}

\begin{abstract}
The paper presents a biography and a professional library in the fields of medicine and obstetrics of Berislav M. Berić, which the Matica Srpska Library received as a donation in 2006. Berislav M. Berić was a respectable specialist physician in the field of gynecology and obstetrics and a university professor from Novi Sad who authored several textbooks and monographs published in the territory of the former Yugoslavia. He dealt with the issues of women's health, human reproduction and family planning, and published numerous scientific papers. Donated collection of Prof. Berić contains a large number of foreign editions that make this collection extremely valuable, as they are very often the only copies of these publications in our country, also indicating the professional interests of the owner of this collection. These are primarily professional publications such as textbooks, practicums, medical lexicons and dictionaries, as well as the collections of papers, press releases and summaries from professional meetings held in the country and abroad.
\end{abstract}

Keywords: Berislav M. Berić, personal libraries, emerging libraries, Matica Srpska Library, history of medicine.

Примљено: 13. марта 2018.

Исправке: 10. априла 2018.

Прихваћено: 8. маја 2018. 